\title{
Relations Between Tourism Spending and Global Competitiveness: an Empirical Study in Developed OECD Countries
}

\author{
Beata Gavurova \\ Technical University of Košice, Faculty of Mining, Ecology, Process Control and Geotechnologies, Institute of \\ Earth Resources, Košice, Slovak Republic \\ Viera Ivankova \\ University of Prešov, Faculty of Management, Prešov, Slovak Republic \\ Martin Rigelsky \\ University of Prešov, Faculty of Management, Prešov, Slovak Republic \\ Magdaléna Př́ívarová \\ University of Economics in Bratislava, Bratislava, Slovak Republic
}

Received: 27 June 2020. Revision received: 2 August 2020. Accepted: 23 August 2020

\begin{abstract}
Global trends indicate a systematic increase in the importance of tourism. From an economic point of view, spending plays an essential role in the spectrum of tourism services indicators. Simultaneously, the competitiveness of economies is a key economic indicator. For this reason, research in this area is considered beneficial. This study's objective was to assess the significance of the structure of clients' spending on tourism in the context of the global competitiveness of OECD countries, with the primary focus on the effect of individual types of tourism spending on competitiveness. Several analytical procedures were used in the processing, such as descriptive analysis, relationship analysis, regression analysis, and cluster analysis. Secondary data were included in the analyses, and these data represented six variables determining tourism spending obtained from the World Travel \& Tourism Council (WTTC) database: i - Business Tourism Spending (BTS), ii - Domestic Tourism Spending (DTS), iii - Internal T\&T Consumption (ITTC), iv - Leisure Tourism Spending (LTS), v - Outbound Travel \& Tourism Expenditure (OTTE), vi - Visitor Exports (Foreign spending) (VEFS); and one variable determining competitiveness: the Global Competitiveness Index (GCI), which was obtained from reports published by the World Economic Forum (WEF). These data were collected for all OECD countries from 2010 to 2018. The results of the regression analysis clearly confirmed the effect of tourism spending on competitiveness in OECD countries. The most significant effects were found in BTS and OTTE, and the least significant impact was identified in VEFS. The results provide valuable information for strategic and development plan makers and institutions responsible for improving the business environment in tourism. The study and its results also offer space for developing national and international benchmarking indicators in this area.
\end{abstract}

Key Words: tourism, global competitiveness index, expenditure, types of tourism spending, World Travel \& Tourism Council, OECD

JEL Classification: L83, F43, R11

Reference: Gavurova, B., Ivankova, V., Rigelsky, M., Přívarová, M. (2020). Relations Between Tourism Spending and Global Competitiveness - an Empirical Study in Developed OECD Countries. Journal of Tourism and Services, 21(11), 38-54. doi: 10.29036/jots.v11i21.175 


\section{JOURNAL OF TOURISM AND SERVICES}

Issue 21, volume 11, ISSN 1804-5650 (Online)

www.jots.cz

\section{Introduction}

Tourism is one of the fastest-growing sectors and represents an important part of the economy of all the member states of the European Union (EU). This is evidenced by the fact that half of these countries recorded a double-digit increase in tourist visits in the first half of 2017, which represented an average increase of up to 5\% compared to the previous year (Csillag, 2018). Maintaining this trend will require the active role of national governments. Tourism has long been considered a predominantly private sector activity, despite the fact that its development depends to a large extent on state support. On the other hand, the state uses tourism as an active tool for regional development, a tool for eliminating regional disparities between regions, as well as within individual regions. Also, the government plays an important role in supporting and shaping the economic and business environment in tourism, in developing increasingly effective tourism tools, and in funding requirements from the state budget as well as local and regional resources (Kljucnikov et al., 2020a). Innovative forms of tourism, including rural and urban tourism, are also important (Kljucnikov et al. 2020b). The role of government is multidimensional, also due to the connection of tourism with the transport sector, which creates increasingly intense causal links, influenced by the processes of globalization. These complex globalization processes also initiate the gradual activities of actors other than the government sector. In some countries, the activities of the non-governmental sector have helped to create effective systems to ensure the development and sustainability of tourism. Competitive aggressiveness has a significant impact on the management of companies (Kljucnikov et al., 2016). In any case, tourism, directly and indirectly, contributes to almost $10 \%$ of gross domestic product (GDP) in the EU, making the EU the world's leading tourist destination with 563 million international arrivals and 30\% of global revenues in 2018 (EC, 2020).

It is undeniable that tourism is an important source of income for individual countries, but also a source of employment and wealth for the country. Tourism is also largely influenced by the geographical characteristics of countries and environmental aspects, while some characteristics and regional specificities can also create an obstacle to its development, e.g., the existence of environmental burdens near the place, which is very attractive for tourists. Many mechanisms are currently being developed to remove obstacles to tourism development, and many countries are looking for optimal tourism management concepts to uncover potential in various localities. For the reasons expressed previously, the development of tourism is also significantly associated with the growth of the country's competitiveness.

The economic effects of tourism can be measured through revenues from domestic and foreign tourism and GDP. Many countries have a tourism financing system composed of the state budget, various local and regional sources of funding, as well as private sources. This heterogeneity in the financing system greatly complicates the basis for comparing total investment in tourism between individual countries and setting benchmarks (Megyesiova and Lieskovska, 2015, 2018). The structure of tourism spending is also important, through which it is possible to quantify the effect on the country's competitiveness. Based on this, it is possible to assess which components of tourism represent the most important area and to reveal other causal links.

This was the motivation of this study, which aimed to assess the significance of the structure of tourism clients' spending in the context of the global competitiveness of OECD countries, with the primary focus on the effect of individual types of tourism spending on competitiveness. The findings provide valuable information for policymakers and other actors in the tourism sector, as well as for regional strategic and development plan makers.

\section{Literature review}




\section{JOURNAL OF TOURISM AND SERVICES}

Issue 21, volume 11, ISSN 1804-5650 (Online)

www.jots.cz

Assessing the causal relationships between the structure of tourism spending and macroeconomic indicators or identifying the determinants of tourism development as well as economic development is very useful in decision-making at practical, political, and scientific levels. The findings below and the research itself confirm the importance of this issue.

As already mentioned, tourism represents a fast-growing economic sector with great potential that contributes to economic prosperity in many countries (Pulido-Fernandez and Pulido-Fernandez, 2018; Stefko et al., 2018). The importance of this issue is underlined by the fact that in 2019, the total contribution of tourism in OECD countries averaged $8.8 \%$ of GDP, and an increasing trend can be observed since 2016 (WTTC, 2020). At the same time, the tourism sector is a relatively complex system influenced by many factors, and therefore this issue requires considerable attention from different perspectives. One of these perspectives may be a macroeconomic view of tourism spending, which can be understood as the driving force of this system. Spending ensures economic prosperity, which translates into the positive macroeconomic output of economies and contributes to sustainable growth. For this reason, tourism spending and its macroeconomic nature is the focus of interest in the presented study.

Tourism spending is a commonly used measure of demand in tourism, and this demand reflects the tourism performance of countries and the global tourism trend (Rossello-Nadal and Jianan, 2019). In this regard, Mayer and Vogt (2016) underlined the importance of tourism spending as a determining factor in the economic impact of tourism itself. At the same time, Pulido-Fernandez et al. (2020) emphasized that the socio-economic status of tourism participants, the specificities of their trip, their activities, and satisfaction are the main factors that create and shape the total tourism spending. Jurdana and Frleta (2017) also argued that tourism consumption is determined by income, accommodation, behaviour, and length of stay. Simultaneously, Tavares et al. (2016) added the repeated visit as a determinant of tourism spending. These factors are in line with the findings by Jang et al. (2004) or Fredman (2008). In general, tourism spending can be divided into main categories characterizing the purpose of meeting the needs of tourists during their stay: accommodation, transport, shopping, food, and beverages (Pellegrini et al., 2020). In this context, Disegna and Osti (2016) revealed that accommodation and food and beverages are the main interlinked categories that affect other spending categories, while satisfaction can be considered as a predictor of spending. Regarding the purpose of the trip, business tourists show higher total spending compared to please tourists, and according to Suh and Gartner (2004), activities at the destination do not appear to correlate with spending. However, the question is how tourism spending affects economic life in individual countries.

From a macroeconomic point of view, the findings of a study conducted by Usmani et al. (2020) showed the positive impact of tourism spending on economic growth, and in this sense, economies should focus on investing in the tourism sector, which can lead to economic benefits. At the same time, the authors emphasized a bidirectional causality between tourism spending and economic growth, explaining that spending in tourism encourages economic growth and vice versa. Similar evidence was found by Corrie et al. (2013), who pointed to the endogenous growth of countries in terms of tourism spending. In any case, tourism and its development are a very important part of economic life in countries, as tourism represents a significant economic contribution that can be considered as a driving force of economic power; simultaneously, economic development is able to support the tourism sector (Durbarry, 2002; Aslan, 2014; Dogru and Bulut, 2018; Pulido-Fernandez and Cardenas-Garcia, 2020). This fact indicates that tourism and economic development cause each other (Kim et al., 2006). Tourism plays an important role in many other economic dimensions, which confirms its potential and scope, even in the light of globalization (Song et al., 2018). On this basis, it can be stated that the economic effects of tourism are substantial in various macroeconomic areas (Archer and Fletcher, 1996; Seetanah, 2011); accordingly, its effect on competitiveness as a whole can be expected.

Dogru et al. (2020) examined the competitiveness of 150 countries on the basis of tourist arrivals and spending, and their findings suggest that Thailand, Japan, and Luxembourg are the most competitive countries. Not only the mentioned study but also other studies focus to a large extent on the 


\section{JOURNAL OF TOURISM AND SERVICES}

Issue 21, volume 11, ISSN 1804-5650 (Online)

www.jots.cz

competitiveness of tourism in individual countries (Crouch, 2011; Assaker et al., 2014; Bucher, 2015; Gomez-Vega and Picazo-Tadeo, 2019), while many studies deal with the Travel \& Tourism Competitiveness Index (TTCI) that includes four sub-indices in areas such as enabling environment, travel and tourism policy and enabling conditions, infrastructure, natural and cultural resources (Kayar and Kozak, 2010; Nazmfar et al., 2019). The essence of TTCI is the measurement of factors and policies that can be reflected in the tourism sector and its development, which contributes to a country's competitiveness and development (WEF, 2019). According to the World Economic Forum (WEF, 2019), countries such as Spain, France, and Germany appear to be the most competitive, while countries such as Yemen, Chad, and Liberia appear at the other end of the scale. On the other hand, the TTCI index does not capture the competitiveness of countries as a whole, and it remains unanswered about how tourism contributes to the global competitiveness of countries. And what can be understood by the term competitiveness of countries? Krugman (1996) explained this as a concept that expresses the fact that countries of the world compete with each other in the same way as companies in individual markets, while a country that does not achieve economic outcomes compared to other countries will face the same difficulties as a company that is unable to achieve the outputs of its rivals. Lall (2001) understands competitiveness as the effort of countries to improve their economic position, overcome market failures, and gain dynamic comparative advantages on the path of growth. The importance of the competitiveness of countries as a key economic aspect is confirmed by the fact that it has been addressed from different perspectives in many international studies (Kordalska and Olczyk, 2016; Perez-Moreno et al., 2016; Fyliuk et al., 2019). The global competitiveness of countries can be assessed using the Global Competitiveness Index (GCI) published by the WEF (2020), which represents a specific set of factors, institutions and policies focused on productivity. When evaluating countries, the index uses a scale from 0 to 100 (until 2017 the scale ranged from 1 to 7), while the highest value represents the optimal situation of countries. The country assessment is based on 12 pillars: (i) institutions, (ii) infrastructure, (iii) information and communications technology adoption, (iv) macroeconomic stability, (v) health, (vi) skills, (vii) product market, (viii) labour market, (ix) financial system, (x) market size, (xi) business dynamism and (xii) innovation capability. It should be noted that the GCI index is a common indicator of competitiveness used by many authors such as Ivanova and Cepel (2018). At the same time, Bucher (2018) emphasized that the GCI index can help create a competitive strategy for countries.

The above-mentioned findings are the basis of the main idea of the presented study, which assumes that tourism itself can affect the competitiveness of countries as a whole. This idea is based on the confirmed fact that tourism, including tourism spending, has an impact on country's economic aspects, while competitiveness is a key economic aspect. On the other hand, this issue has been examined to a small extent from a macroeconomic point of view, and therefore this study fills this gap and clarifies whether a country seeking comparable economic outputs should effectively focus on the tourism sector. These facts formed the basis for fulfilling the objective of the study, which was to assess the significance of the structure of clients' spending on tourism in the context of the global competitiveness of OECD countries, with the primary focus on the effect of individual types of tourism spending on competitiveness.

\section{Methods}

Several consecutive analytical procedures were selected to meet the set objective. In the first phase, a statistical description of the data was performed. Subsequently, relationship analysis and regression analysis were applied, and the third stage was devoted to cluster analysis.

The research sample consisted of 36 countries of the Organisation for Economic Co-operation and Development (OECD). These countries were listed with the Alpha-3 code according to the international classification ISO 3166-1 (AUS, AUT, BEL, CAN, CZE, DEU, DNK, ESP, EST, FIN, 


\section{JOURNAL OF TOURISM AND SERVICES}

Issue 21, volume 11, ISSN 1804-5650 (Online)

www.jots.cz

FRA, GBR, GRC, HUN, CHE, CHL, IRL, ISL, ISR, ITA, JPN, KOR, LTU, LUX, LVA, MEX, NLD, NOR, NZL, POL, PRT, SVK, SVN, SWE, TUR, USA). The analysis included tourism data (spending of tourism clients) and competitiveness data for the period from 2010 to 2018. The tourism data consisted of six variables: (i) Business Tourism Spending (BTS) - spending on business travel within a country by residents and international visitors; (ii) Domestic Tourism Spending (DTS) - spending within a country by that country's residents for both business and leisure trips. Multi-use consumer durables are not included since they are not purchased solely for tourism purposes. This is consistent with total domestic tourism expenditure. (iii) Internal Travel and Tourism Consumption (ITTC) - total revenue generated within a country by industries that deal directly with tourists including visitor exports, domestic spending and government individual spending. This does not include spending abroad by residents. (iv) Leisure Tourism Spending (LTS) - spending on leisure travel within a country by residents and international visitors. (v) Outbound Travel \& Tourism Expenditure (OTTE) - spending outside the country by residents on all trips abroad. This is fully aligned with total outbound tourism expenditure. (vi) Visitor Exports (Foreign spending) (VEFS) - spending within the country by international tourists for both business and leisure trips, including spending on transport, but excluding international spending on education. This is consistent with total inbound tourism expenditure (WTTC, 2020). Subsequently, these data were standardized per capita in each country and per thousand USD. Country population data were obtained from the World Bank database (WB, 2020). The competitiveness of economies was represented by the Global Competitiveness Index (GCI) and the data were obtained from reports of the World Economic Forum (WEF, 2020). The GCI reporting methodology changed in 2018, while until 2017 (inclusive) a scale from 1 to 7 was used, since 2018 it changed to a scale in the interval from 0 to 100 . All analysed data were transformed into this interval, indicating the higher the value, the more positive the output of competitiveness.

Based on the nature of the data and the objective of the research, a regression analysis was chosen. In the first step, tests of the use of a simple linear regression were performed, first the presence of significant outliers was assessed using the Bonferroni Outlier Test (Fox and Weisberg, 2019). Subsequently, the presence of significant heteroscedasticity was tested using the Breusch-Pagan Test (Breusch and Pagan, 1979). Based on the Gauss-Marks theorem, the assumption of homoscedasticity (constant variability of residues) is of great importance, which is emphasized for the Best Linear Unbiased Estimator (BLUE) by the elimination of the presence of multicollinearity and heteroscedasticity. As a simple model of linear regression was chosen, the multicollinearity is irrelevant, but in the case of the presence of heteroscedasticity, the coefficients were estimated using the HC3 estimator (White, 1980). In addition to the regression analysis, several analytical procedures were also applied. Within a descriptive statistics, the basic statistical characteristics (arithmetic mean (Mean), lower and upper bound of $95 \%$ confidence interval for the mean (95\% CI LB, 95\% CI UB), Median, standard deviation (Std.Dev.), Minimum, Maximum, $1^{\text {st }}$ Quartile, $3^{\text {rd }}$ Quartile, interquartile range (IQR), Skewness, Kurtosis) were used in the first-level classification into variables that determine the spending of tourism clients and the competitiveness of countries. A relationship analysis was also applied using the Spearman coefficient $\varrho$, which was selected based on the outputs of the Royston multivariate normality test (Royston, 1980). Finally, a cluster analysis was applied using the Ward method and the number of clusters (groups) was estimated using the silhouette method - for average silhouette width (Struyf et al., 1996). The cluster analysis included adjusted data in the numerical interval from 0 to 1 , where 1 represents the most positive evaluation. Other procedures are described in more detail in their application in the following section. The programming language $\mathrm{R}$ v. 3.6.3 (Holding the Windsock) was used for analytical processing in $\mathrm{R}$ Studio - RStudio, Inc., Boston, MA, U.S. (R Core Team, 2020). The R packages as MNV (Korkmaz et al., 2014), lmtest (Zeileis and Hothorn, 2002), sandwich (Zeileis, 2004), cluster (Maechler et al., 2019), factorextra (Kassambara and Mundt, 2020) helped with statistical computations. 


\section{JOURNAL OF TOURISM AND SERVICES}

Issue 21, volume 11, ISSN 1804-5650 (Online)

www.jots.cz

\section{Results}

This section presents the outputs of the analyses carried out in order to meet the main objective. The analytical process can be divided into three separate parts, which are in a logical order (according to the methodological procedure in the previous section).

Table 1. Descriptive statistics

\begin{tabular}{lccccccc}
\hline Descriptive & BTS & DTS & ITTC & LTS & OTTE & VEFS & GCI \\
\hline \hline Mean & 0.59 & 1.57 & 2.95 & 2.36 & 0.96 & 1.38 & 70.55 \\
95\% CI LB & 0.54 & 1.45 & 2.68 & 2.13 & 0.87 & 1.19 & 69.77 \\
95\% CI UB & 0.64 & 1.69 & 3.22 & 2.59 & 1.06 & 1.58 & 71.32 \\
Median & 0.54 & 1.20 & 2.45 & 1.85 & 0.73 & 0.88 & 72.00 \\
Std.Dev. & 0.49 & 1.10 & 2.45 & 2.10 & 0.86 & 1.82 & 7.13 \\
Minimum & 0.06 & 0.12 & 0.36 & 0.28 & 0.04 & 0.07 & 46.86 \\
Maximum & 3.86 & 4.56 & 16.54 & 12.68 & 5.59 & 12.05 & 85.60 \\
$1^{\text {st }}$ Quartile & 0.21 & 0.60 & 1.22 & 1.05 & 0.36 & 0.51 & 64.18 \\
$3^{\text {rd }}$ Quartile & 0.85 & 2.45 & 3.54 & 2.69 & 1.30 & 1.48 & 76.69 \\
IQR & 0.64 & 1.85 & 2.32 & 1.64 & 0.94 & 0.97 & 12.51 \\
Skewness & 2.82 & 0.60 & 2.54 & 2.53 & 1.98 & 3.59 & -0.25 \\
Kurtosis & 14.39 & -0.76 & 8.78 & 7.46 & 5.52 & 14.04 & -0.76 \\
\hline \hline
\end{tabular}

Source: Elaborated by the authors.

Table 1 provides a statistical description of the examined indicators. The confidence interval for arithmetic mean can be considered the most valuable and appropriate characteristic. As can be assumed, the highest average value was found in the ITTC variable (CI 95\%: 2.68 - 3.22). More interesting is the comparison of non-aggregated spending indicators, within which the BTS variable acquired the lowest mean values (CI 95\%: 0.54 - 0.64), thus business-oriented tourism clients in OECD countries spend an average of about 590 USD per capita. Business-oriented tourism is relatively young, but its potential is currently very large. When comparing the spending of domestic tourism clients and the spending of foreign tourism clients in OECD countries in the analysed period (CI 95\%: DTS $=1.45-1.69$; VEFS = 1.19 - 1.58), higher values were found in the DTS variable, while the average amount of spending per capita was approximately 1,570 USD. When focusing on the Global Competitiveness Index - GCI, it can be stated that the values agree with the expectation of a higher rate, as the OECD is represented by developed countries. Table 2 shows the relationship between tourism spending indicators and competitiveness.

Table 2. Relationship analysis

\begin{tabular}{lrrrrrr}
\hline GCI & BTS & DTS & ITTC & LTS & OTTE & VEFS \\
\hline \hline Royston H & 115.9943 & 75.2515 & 117.8701 & 123.2123 & 104.9025 & 147.0418 \\
p value & $<0.0000$ & $<0.0000$ & $<0.0000$ & $<0.0000$ & $<0.0000$ & $<0.0000$ \\
\hline Spearman's $\varrho$ & 0.7007 & 0.6100 & 0.5314 & 0.4382 & 0.6057 & 0.1722 \\
p value & $<2.2 \times 10^{-16}$ & $<2.2 \times 10^{-16}$ & $<2.2 \times 10^{-16}$ & $<2.2 \times 10^{-16}$ & $<2.2 \times 10^{-16}$ & $1.86 \times 10^{-3}$ \\
\hline \hline
\end{tabular}

Note: Royston H - Royston multivariate normality test

Source: Elaborated by the authors. 


\section{JOURNAL OF TOURISM AND SERVICES}

Issue 21, volume 11, ISSN 1804-5650 (Online)

www.jots.cz

Table 2 is divided into two parts, while the first part provides the outputs of the assessment of multivariate normality, the second part evaluates the associations. As can be seen in the table, significant differences from the normal distribution were identified in all tested cases ( $p$-value $<0.05$ ). A nonparametric Spearman correlation coefficient $\varrho$ was used to determine the relation. With a focus on evaluating the significance of associations, all cases showed a significant rate of association based on the $p$-value ( $p$-value $<0.05)$. A very strong association was found in the BTS variable $(\varrho=0.70)$, a substantial to very strong association was identified in DTS $(\varrho=0.61)$, ITTC $(\varrho=0.53)$ and OTTE $(\varrho=0.61)$. In the case of the LTS variable $(\varrho=0.44)$, the rate of association can be interpreted as medium to substantial, and finally the VEFS variable $(\varrho=0.17)$ showed a low to medium rate. All coefficients are positive, and therefore an increase in tourism spending may be associated with an increase in competitiveness, especially for variables with a higher rate of significant association. The assessment of the significance of the effect of selected variables on competitiveness is the subject of the following parts.

Table 3. Testing the assumptions for a simple linear regression analysis

\begin{tabular}{|c|c|c|c|c|c|c|}
\hline $\begin{array}{l}\text { Test / } \\
\text { model }\end{array}$ & mBTS & mDTS & mITTC & mLTS & mOTTE & mVEFS \\
\hline $\begin{array}{l}\text { Outliers } \\
\text { (BT) }\end{array}$ & $\begin{array}{c}\text { CHE(2012); } \\
\text { ISL(2017) }\end{array}$ & $\begin{array}{c}\text { CHE(2012, } \\
\text { 2013) }\end{array}$ & CHE(2012) & CHE(2012) & $\begin{array}{c}\text { CHE(2012, } \\
2013)\end{array}$ & - \\
\hline $\mathrm{BP}$ & 115.27 & 1.4591 & 4.2241 & 0.063 & 7.5126 & 3.8484 \\
\hline $\mathrm{p}$ value & $<0.0000$ & 0.2271 & 0.0399 & 0.8019 & 0.0061 & 0.0498 \\
\hline Estimate & HC3 & OLS & HC3 & OLS & HC3 & HC3 \\
\hline
\end{tabular}

Note: Outliers (BT) - Bonferroni Outlier Test; BP - Breusch-Pagan Test

Source: Elaborated by the authors.

Table 3 is the starting point for selecting an appropriate test that determines the significance of the effect of the analysed relations. Individual models are identified according to the selected independent variables. In the first step, the analysis evaluating the statistical significance of outliers was applied.

Table 4. Output of regression analysis

\begin{tabular}{llrrrrrr}
\hline Model & Coefficients & Estimate & Std. Error & t value & $\operatorname{Pr}(>|\mathbf{t}|)$ & CI 2.5 \% & CI 97.5 \% \\
\hline \hline \multirow{2}{*}{ mBTS } & Intercept $(\alpha)$ & 65.924 & 1.0352 & 63.6809 & $<2.2 \times 10^{-16}$ & 63.8873 & 67.9607 \\
& BTS $(\beta)$ & 8.0938 & 1.936 & 4.1807 & $3.76 \times 10^{-5}$ & 4.285 & 11.9027 \\
\hline \multirow{2}{*}{ mDTS } & Intercept $(\alpha)$ & 64.7906 & 0.5406 & 119.85 & $<2.2 \times 10^{-16}$ & 63.727 & 65.8541 \\
& DTS $(\beta)$ & 3.7806 & 0.284 & 13.31 & $<2.2 \times 10^{-16}$ & 3.2219 & 4.3394 \\
\hline \multirow{2}{*}{ mITTC } & Intercept $(\alpha)$ & 67.7741 & 0.6414 & 105.66 & $<2.2 \times 10^{-16}$ & 66.5121 & 69.036 \\
& ITTC $(\beta)$ & 0.9662 & 0.1981 & 4.8762 & $1.7 \times 10^{-6}$ & 0.5764 & 1.356 \\
\hline \multirow{2}{*}{ mLTS } & Intercept $(\alpha)$ & 68.4376 & 0.5643 & 121.271 & $<2.2 \times 10^{-16}$ & 63.727 & 65.8541 \\
& LTS $(\beta)$ & 0.9264 & 0.1789 & 5.178 & $3.9 \times 10^{-7}$ & 3.2219 & 4.3394 \\
\multirow{2}{*}{ mOTTE } & Intercept $(\alpha)$ & 67.0486 & 0.653 & 102.679 & $<2.2 \times 10^{-16}$ & 65.7639 & 68.3333 \\
& OTTE $(\beta)$ & 3.8065 & 0.6447 & 5.9039 & $9.05 \times 10^{-9}$ & 2.538 & 5.0749 \\
\hline \multirow{2}{*}{ mVEFS } & Intercept $(\alpha)$ & 69.9947 & 0.4708 & 148.664 & $<2.2 \times 10^{-16}$ & 69.0684 & 70.921 \\
& VEFS $(\beta)$ & 0.3979 & 0.1252 & 3.1781 & $1.63 \times 10^{-3}$ & 0.1516 & 0.6441 \\
\hline \hline
\end{tabular}

Source: Elaborated by the authors.

The first row of the table shows the individual data that were evaluated as outliers and subsequently removed. In the second step, the analysis of constant variability of residues (homoscedasticity) was applied, while the presence of significant heteroscedasticity was detected in the 


\section{JOURNAL OF TOURISM AND SERVICES}

Issue 21, volume 11, ISSN 1804-5650 (Online)

www.jots.cz

BTS, ITTC, OTTE and VEFS models. Analogously, the White method of HC3 was chosen to estimate the coefficients for the mentioned models. In the case of other models, the Ordinary Least Squares model was chosen to estimate the coefficients. Table 4 shows the outputs of the models, i.e. one of the most important results of the analysis with respect to the fulfilment of the primary objective.

Table 4 provides the outputs of all models assessing the causal relationship between the indicators of tourism spending from a client perspective and the competitiveness of countries. The primary focus of the research in this study is to assess the statistical significance of the effects of tourism spending on competitiveness. The most important statistical characteristic is therefore the asymptotic significance in the column $\operatorname{Pr}(>|t|)$. As can be seen, the causal relationship proved to be significant in all cases at the $\alpha$ level of less than 0.05 and simultaneously significant in all but one case (VEFS) at the $\alpha$ level of less than 0.001. Based on this, it can be concluded that these tourism indicators have a significant effect on competitiveness expressed by the GCI indicator. It is also possible to secondarily assess the direction and intensity of effects. All coefficients acquired positive values, thus an upward trend is evident, as shown in Figure 1.

\section{Figure 1. Decile plot of GCI prediction}

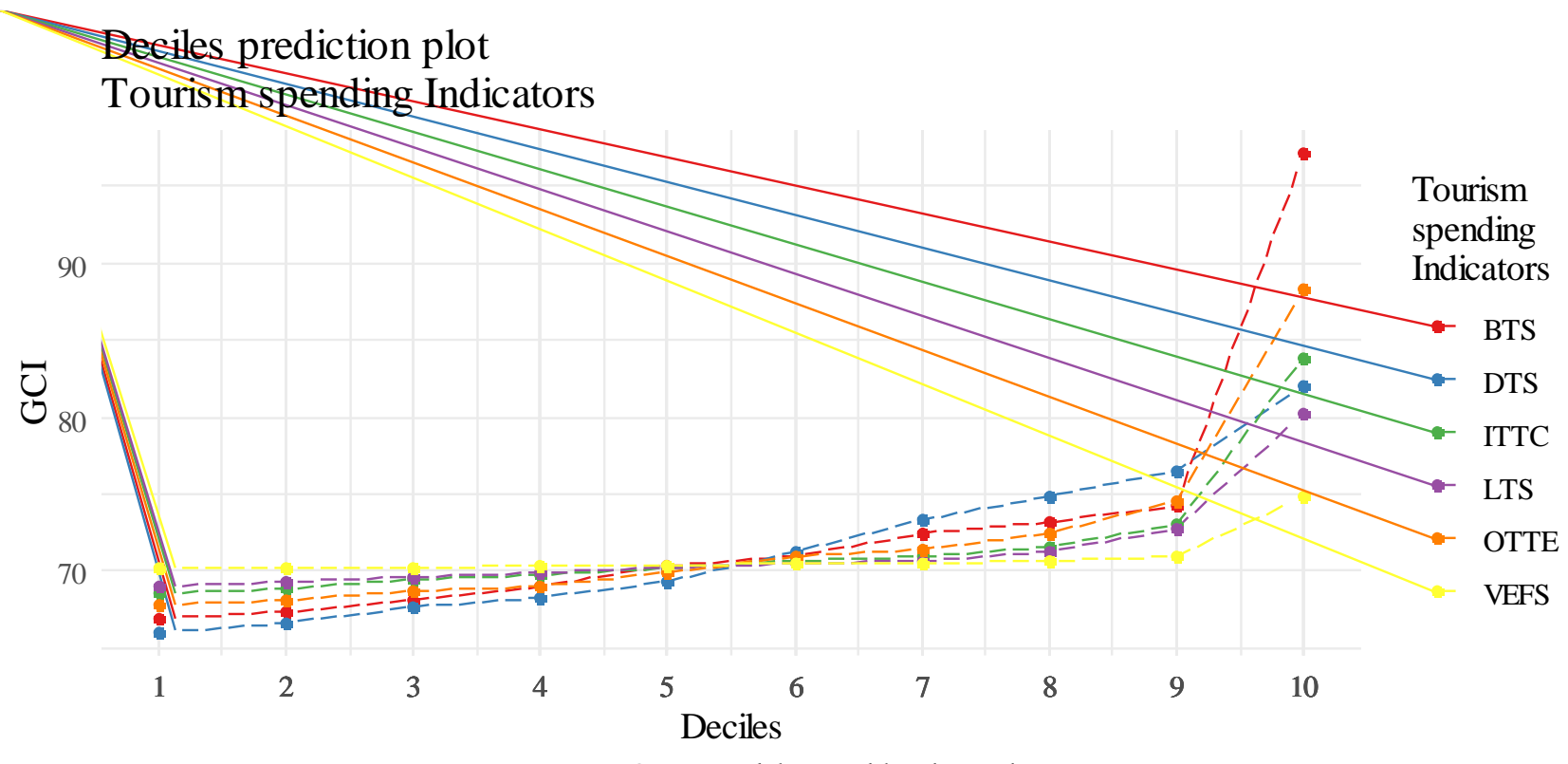

Source: Elaborated by the authors.

Figure 1 shows the prediction curves of the GCI index in decile values of the selected indicators of tourism spending. From this it is possible to obtain primarily two main pieces of information, and thus the intensity of the effect and the distribution of values in deciles. The intensity of the effect can be assessed on the basis of the slope (steepness) of the distribution of decile values (slope of the curve). The BTS variable showed the steepest trajectory, therefore the greatest effect can be expected in this case. On the other hand, the least steep trajectory is in the VEFS variable. It is also necessary to point out the fact that the break of the curve can be seen in the $9^{\text {th }}$ decile, where the curve is the steepest, i.e. the greatest effects of individual indicators were at $10 \%$ observations with the highest rate of tourism spending.

The final part of the analytical process is focused on the application of cluster analysis, which aimed to divide countries according to their greatest similarity (within the group) and also according to the greatest difference (compared to other groups) in the examination of selected tourism spending and competitiveness. The first step in the pre-processing of the data was to calculate the mean value for each variable in each year and each country. For this operation, it was necessary to select the most suitable 


\section{JOURNAL OF TOURISM AND SERVICES}

Issue 21, volume 11, ISSN 1804-5650 (Online)

www.jots.cz

characteristic of the mean value. For this purpose, a nonparametric difference test was applied, the output of which is shown in Table 5.

Based on the p-values, it can be concluded that the only significant difference was found in the GCI variable, therefore in all cases except the GCI indicator, the arithmetic mean was used to calculate the mean value of the years for individual countries. In the case of the GCI indicator, the median was used.

Table 5. Difference test (Kruskal Wallis test)

\begin{tabular}{lrrrrrrr}
\hline Year & BTS & DTS & ITTC & LTS & OTTE & VEFS & GCI \\
\hline \hline Kruskal Wallis $\chi^{2}$ & 1.85 & 1.20 & 4.27 & 3.79 & 2.90 & 4.68 & 18.95 \\
p value & 0.9853 & 0.9966 & 0.8318 & 0.8759 & 0.9406 & 0.7910 & 0.0152 \\
\hline \hline
\end{tabular}

Source: Elaborated by the authors.

This was followed by a step in which the values were standardized from 0 to 1 , while 1 represents the most positive result. Through this process, the indicators have acquired a new dimension, which consists in the evaluation of selected areas. Subsequently, the evaluations of tourism spending were recalculated by the arithmetic mean. Based on this, two new variables were created: the variable indicating the evaluation of tourism spending (TS_eval) and the variable indicating the evaluation of competitiveness (GCI_eval). These variables were included in the cluster analysis, in the first step the most appropriate number of clusters was estimated and three clusters were recommended using the silhouette method. Several models of cluster analysis were applied, and based on the agglomerative coefficient $(\mathrm{ac}=0.95)$, the Ward method appeared to be the most appropriate method. Figure 2 shows the output of the cluster analysis.

Figure 2. Cluster dendrogram - relations between TS_eval and GCI_eval

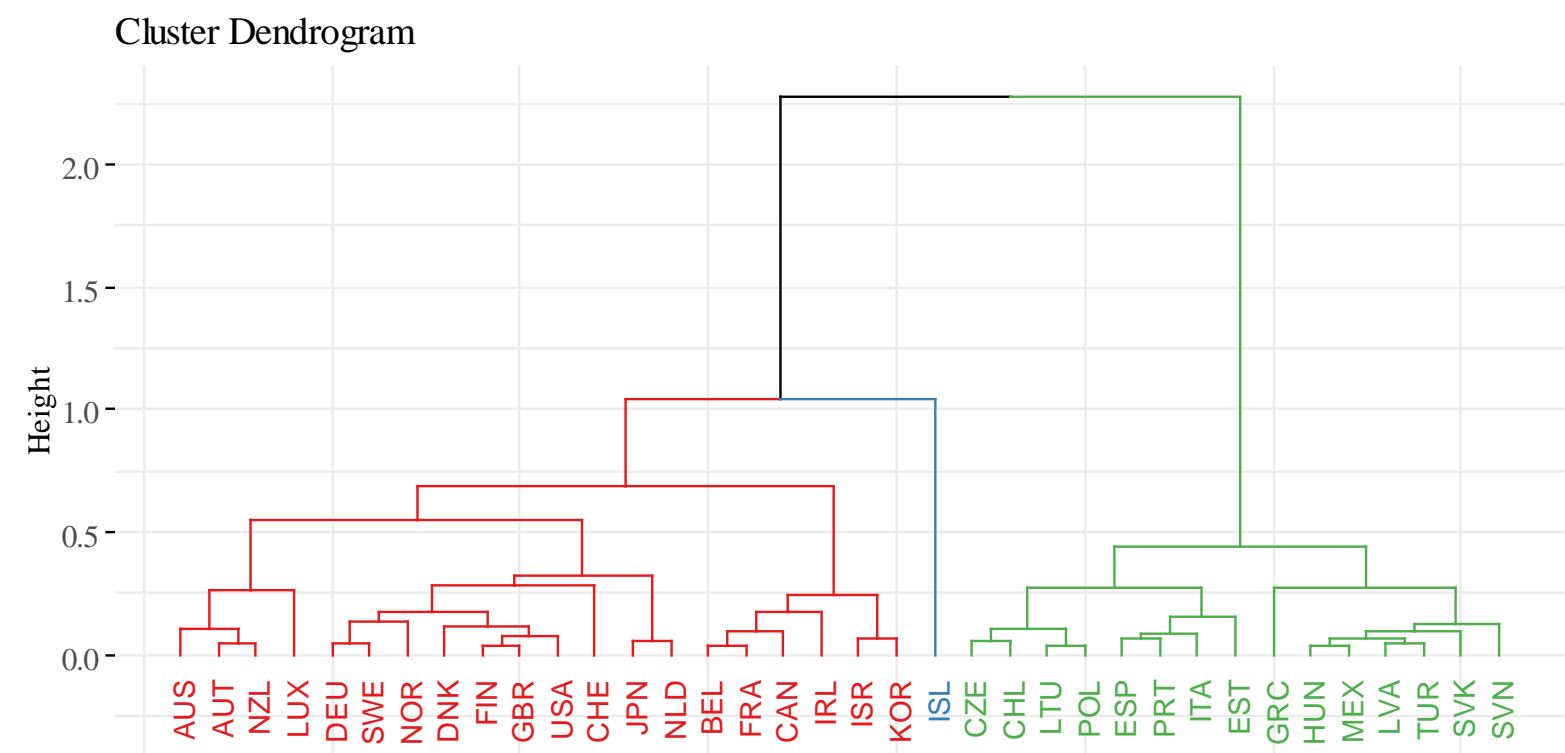

Source: Elaborated by the authors.

The first cluster consists of countries such as AUS, AUT, BEL, CAN, DEU, DNK, FIN, FRA, GBR, CHE, IRL, ISR, JPN, KOR, LUX, NLD, NOR, NZL, SWE, USA, while the average value of TS_eval was 0.30, GCI_eval showed 0.73. The second cluster includes countries such as CZE, ESP, EST, 


\section{JOURNAL OF TOURISM AND SERVICES}

Issue 21, volume 11, ISSN 1804-5650 (Online)

www.jots.cz

GRC, HUN, CHL, ITA, LTU, LVA, MEX, POL, PRT, SVK, SVN, TUR, in which the average value of TS_eval showed 0.10 and the average value of GCI_eval was 0.25 . The last cluster consists of only one country, Iceland, which acquired TS_eval of 0.99 and GCI_eval of 0.43 . Based on the above, it can be concluded that the first cluster is represented by countries that have the values of both indicators at a relatively high level. Iceland, which has also acquired a relatively high level of evaluation of indicators, is closer to the first cluster than to the second. The second cluster groups countries with lower and less positive results compared to previous clusters. In addition to the assessment of these main groupings, it is also possible to assess countries on the basis of an individual level of interconnection, e.g. AUT is very similar to NZL in the analysed relation and these two countries are very similar to AUS.

\section{Figure 3. Cluster plot - relations between TS_eval and GCI_eval}

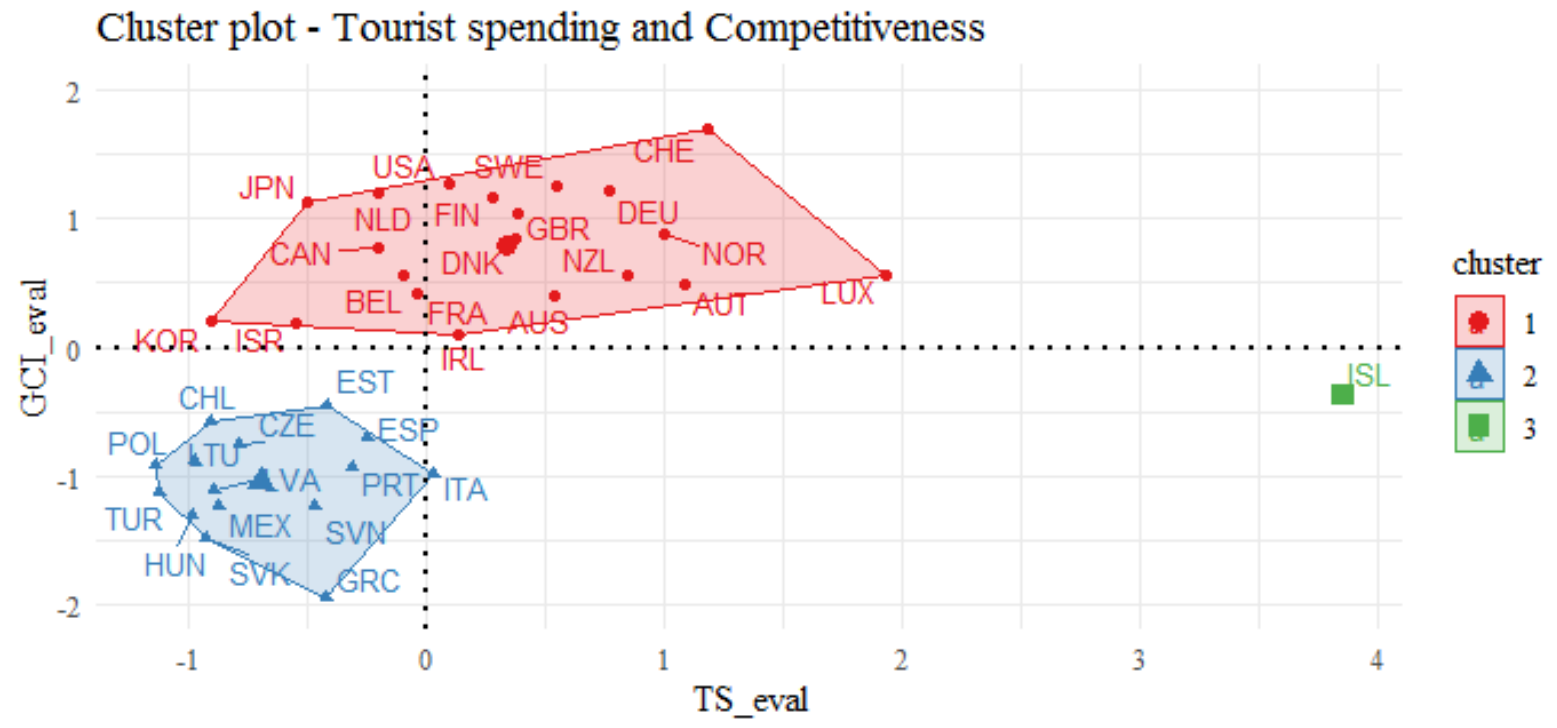

Source: Elaborated by the authors.

Figure 3 shows the relations between the countries in the analysed areas in accordance with the clusters presented in Figure 2. The figure clearly shows the results interpreted above. The left quadrant at the bottom represents the countries of the second cluster, which are characterized by a low average evaluation of competitiveness as well as tourism spending. The countries in the upper right quadrant can be assessed very positively. Iceland is a specific country with a very high rate of tourism spending evaluation and a lower rate of competitiveness evaluation.

\section{Discussion}

As pointed out in theoretical knowledge, tourism is a very important element of economic life (Durbarry, 2002; Dogru and Bulut, 2018). Therefore, research efforts should focus on this issue and pay attention to the links between the various components of tourism and the economy. In any case, it is clear that the development of tourism contributes positively to the economic prosperity of the countries (Seetanah, 2011; Aslan, 2014). Also, the bidirectional causal relationship can be emphasized (Kim et al., 2006; Pulido-Fernandez and Cardenas-Garcia, 2020). Based on this, it is clear that business and government activities should focus on increasing tourism development. In addition to economic growth, the key economic indicator is the competitiveness of countries, while its relationship with tourism is evident. 


\section{JOURNAL OF TOURISM AND SERVICES}

Issue 21, volume 11, ISSN 1804-5650 (Online)

www.jots.cz

The presented study focuses on examining the relationships between selected types of tourism spending and the global competitiveness of OECD countries, with a primary focus on the effect of tourism spending on competitiveness. The results of the analyses showed interesting findings. It can be emphasized that the highest average value of per capita spending in individual countries was found in the indicator of Internal T\&T Consumption (ITTC), which was expected, as this category includes the consumption of tourism clients as well as government subsidies. The second highest indicator was Leisure Tourism Spending (LTS), which takes into account the spending of domestic and foreign tourists. The difference between ITTC and LTS defines an approximate level of support, which represents an average of 590 USD per capita in OECD countries during the analysed period. Domestic Tourism Spending (DTS) provides a relatively significant part of tourism revenues. On the other hand, the smallest part of the revenues comes from Business Tourism Spending (BTS). However, this finding does not agree with the statement that business tourists have a higher total spending compared to pleasure tourists (Suh and Gartner, 2004).

The essence of the applied relationship analysis was to point out the existence of different relationships between the analysed variables. The significant relationship was confirmed in all cases of the examined relations, but this fact does not mean that the GCI index is necessarily influenced by a particular spending indicator. In the case of the BTS, DTS, ITTC and OTTE indicators, it is possible to speak of substantial, strong to very strong associations. The association at the medium to substantial level can be seen in the LTS indicator, and the association at the low to medium level in the VEFS indicator.

The significant effects of tourism spending were confirmed by regression analysis. Based on this output, it is possible to talk about the significance of the effects of tourism spending indicators on the competitiveness of economies. In terms of economic growth, the effect of tourism spending was confirmed by Corrie et al. (2013) and Usmani et al. (2020). These findings are comparable from an economic perspective. In this study, the most significant effects were found in BTS and OTTE, while the BTS indicator has the greatest connection to the economy in the analysed areas. Also, the OTTE indicator can be associated with the enrichment of experience and knowledge, which is essential for the competitiveness of countries.

The last part of the outputs was obtained by applying the cluster analysis, which assessed individual countries on the basis of their interconnection in the areas of tourism spending evaluation and competitiveness evaluation. The outputs of this analysis revealed the existence of a link between clients' spending on tourism and competitiveness, which supports the findings presented by relationship and regression analysis. The countries of the second cluster, which includes CZE, ESP, EST, GRC, HUN, CHL, ITA, LTU, LVA, MEX, POL, PRT, SVK, SVN, TUR, showed lower values of tourism spending and competitiveness evaluations. Accordingly, these countries create potential and opportunities for improvement. The cluster with more positive outputs consists of countries such as AUS, AUT, BEL, CAN, DEU, DNK, FIN, FRA, GBR, CHE, IRL, ISR, JPN, KOR, LUX, NLD, NOR, NZL, SWE, USA. These findings can be compared with the evaluation of the competitiveness of tourism in other studies and reports (WEF, 2019; Dogru et al., 2020).

From the above-mentioned, it can be stated that the main results of the study are in line with the idea that tourism has a positive effect on various aspects of economic life, including competitiveness. In other words, tourism can be considered a source of competitiveness for countries. Therefore, it is very important to focus on the development of tourism in order to increase client interest, which can be reflected in increased spending and, by analogy, in economic prosperity. Tourism enterprises should focus on customer needs and satisfaction in order to increase their willingness to spend money at the destination. There are several methods that could be useful for quality management teams (Jenco and Cernak, 2019). This study reveals that tourism spending is undoubtedly an important key factor not only in terms of economic growth but also in terms of competitiveness. At the same time, the structure of this spending should be taken into account. Public policymakers should also be aware of these facts in the decision-making process of supporting the tourism sector, with an emphasis on achieving comparable 


\section{JOURNAL OF TOURISM AND SERVICES}

Issue 21, volume 11, ISSN 1804-5650 (Online)

www.jots.cz

economic outcomes. In any case, the economic life of countries and the tourism sector are highly interconnected areas, and therefore public policy decisions should be coordinated.

\section{Conclusion}

Tourism is a fast-growing service sector whose positive effects on economic prosperity are well known. The most important unit in tourism is the client, who is the driving force of this sector. Also, the competitiveness of countries is an indicator that should not be underestimated, but on the other hand, it is possible to talk about insufficient research activities in this issue. In the research area, there are not many studies examining the relationships between the individual types of tourism spending and the competitiveness of countries. The interconnection of these two subsystems of economic life is highly desirable from a macroeconomic point of view. The OECD includes countries that are characterized by their economic development, and therefore it can be assumed that their tourism sector is also developed and balanced. The presented study provides insight into this issue.

Secondary data were used in the analyses, and these data represented six variables determining tourism spending (BTS, DTS, ITTC, LTS, OT'TE, VEFS) and one variable determining competitiveness (GCI). The objective of this study was to assess the significance of the structure of clients' spending on tourism in the context of the global competitiveness of OECD countries, with the primary focus on the effect of individual types of tourism spending on competitiveness. Based on the results of the analyses, a significant effect on competitiveness can be confirmed in all types of tourism spending, but in the case of the VEFS indicator, the effect seems to be less significant compared to other types of spending.

The conclusions of several studies in this area clearly encourage business entities to create a quality tourism offer leading to the development of tourism. As a result, activities aimed at increasing the attractiveness of tourism services will lead to an increase in spending of tourism clients and, by analogy, to an increase in macroeconomic indicators.

According to the results of the research, Business Tourism Spending has the most significant effect on competitiveness; it is a young and intensively developing form of tourism. The Global Competitiveness Index consists of pillars that business-oriented tourism helps to develop. Business Tourism Spending does not only include travel spending of business people but also spending on congress tourism, which is a source of information exchange, building partnerships, or creating new visions. These aspects are an integral part of the development of competitiveness in countries. The processes of globalization and internationalization will continue to support the development of business activities at the national and international level; therefore spending on business tourism is expected to increase. Tourism entrepreneurs themselves must be able to handle this. As a result, tourism entrepreneurs face challenges in the form of creating effective strategies to ensure their business prosperity, as well as the development and sustainability of tourism. New forms of tourism associated with business tourism spending will also place relatively higher demands on entry into this sector, for which the business sector must prepare. At the same time, it requires governments to improve the business environment in tourism, create optimal conditions for the implementation of new innovative forms of tourism development and look for new ways to increase the attractiveness of regions in order to ensure stable regional development. In addition to government institutions, this issue also provides significant space for other tourism actors, whose strategic orientation could be aimed at ensuring sustainable tourism in the country. During this period, when the vast majority of countries are severely affected by the COVID-19 crisis, the importance of institutional support and other actors will become increasingly important. Countries face a major challenge in building strategic tourism development systems that also reflect potential global threats and risks.

This research could not avoid limitations due to the fact that data for a certain period of time were included in the analytical process, as it can be assumed that with increasing time period, the probability of the effect of other hidden quantities also increases. The research sample of OECD 


\section{JOURNAL OF TOURISM AND SERVICES}

Issue 21, volume 11, ISSN 1804-5650 (Online)

www.jots.cz

countries can be considered relevant and sufficient in terms of the representativeness of outputs. The extension of the time series and the assessment of the effects of the countries themselves will be included in analyses of future research. Future research will also examine the relations between tourism spending and other economic outputs, including the country's attractiveness parameters, the degree of environmental burdens, and other specificities that have a significant impact on tourism development and sustainability. At the same time, it is possible to discuss the endogenous effect, which will also be investigated in future research.

\section{Acknowledgments:}

This work is supported by the Scientific Grant Agency of the Ministry of Education, Science, Research, and Sport of the Slovak Republic and the Slovak Academy Sciences as a part of the research project VEGA 1/0797/20: "Quantification of Environmental Burden Impacts of the Slovak Regions on Health, Social and Economic System of the Slovak Republic" and APVV-17-0166 "Economic and psychological factors of tourists' expenditures: microeconometric modeling".

\section{References}

1. Archer, B. \& Fletcher, J. (1996). The economic impact of tourism in the Seychelles. Annals of Tourism Research, 23(1), 32-47. doi: 10.1016/0160-7383(95)00041-0

2. Aslan, A. (2014). Tourism development and economic growth in the Mediterranean countries: evidence from panel Granger causality tests. Current Issues in Tourism, 17(4), 363-372. doi: 10.1080/13683500.2013.768607

3. Assaker, G., Hallak, R., Vinzi, V. E. \& O'Connor, P. (2014). An empirical operationalization of countries' destination competitiveness using partial least squares modeling. Journal of Travel Research, 53(1), 26-43. doi: 10.1177/0047287513481275

4. Breusch, T. S. \& Pagan, A. R. (1979). A simple test for heteroscedasticity and random coefficient variation. Econometrica, 47(5), 1287-1294.

5. Bucher, S. (2015). Tourism competitiveness in European destinations: measuring of the tourism competitiveness index. Ekonomicky Casopis, 63(6), 634-655.

6. Bucher, S. (2018). The Global Competitiveness Index as an indicator of sustainable development. Herald of The Russian Academy of Sciences, 88(1), 44-57. doi: 10.1134/S1019331618010082

7. Corrie, K., Stoeckl, N. \& Chaiechi, T. (2013). Tourism and economic growth in Australia: an empirical investigation of causal links. Tourism Economics, 19(6), 1317-1344. doi: $10.5367 /$ te.2013.0241

8. Crouch, G. I. (2011). Destination competitiveness: an analysis of determinant attributes. Journal of Travel Research, 50(1), 27-45. doi: 10.1177/0047287510362776

9. Csillag, K. (2018). Riadenie oblastí cestovnébo ruchu v členských štátoch EÚ. Informačný materiál č. 14/2018, 1-23. Retrieved July 24, 2020, from www.nrsr.sk

10. Disegna, M. \& Osti, L. (2016). Tourists' expenditure behaviour: the influence of satisfaction and the dependence of spending categories. Tourism Economics, 22(1), 5-30. doi: $10.5367 /$ te. 2014.0410

11. Dogru, T. \& Bulut, U. (2018). Is tourism an engine for economic recovery? Theory and empirical evidence. Tourism Management, 67, 425-434. doi: 10.1016/j.tourman.2017.06.014

12. Dogru, T., Suess, C. \& Sirakaya-Turk, E. (2020). Why do some countries prosper more in tourism than others? Global competitiveness of tourism development. Journal of Hospitality \& Tourism Research, UNSP 1096348020911706. doi: 10.1177/1096348020911706

13. Durbarry, R. (2002). The economic contribution of tourism in Mauritius. Annals of Tourism Research, 29(3), 862-865. doi: 10.1016/S0160-7383(02)00008-7 


\section{JOURNAL OF TOURISM AND SERVICES}

Issue 21, volume 11, ISSN 1804-5650 (Online)

www.jots.cz

14. EC (2020). Cestovný ruch a doprava v roku 2020 a v dalsom období. Retrieved July 24, 2020, from https://ec.europa.eu/transparency/regdoc/rep/1/2020/SK/COM-2020-550-F2-SK-MAINPART-1.PDF

15. Fox, J. \& Weisberg, S. (2012). An R companion to applied regression. Third Edition. Thousand Oaks: Sage.

16. Fredman, P. (2008). Determinants of visitor expenditures in mountain tourism. Tourism Economics, 14(2), 297-311. doi: 10.5367/000000008784460418

17. Fyliuk, H., Honchar, I. \& Kolosha, V. (2019). The interrelation between economic growth and national economic competitiveness: the case of Ukraine. Journal of Competitiveness, 11(3), 5369. doi: $10.7441 /$ joc. 2019.03 .04

18. Gomez-Vega, M. \& Picazo-Tadeo, A. J. (2019). Ranking world tourist destinations with a composite indicator of competitiveness: To weigh or not to weigh? Tourism Management, 72, 281-291. doi: 10.1016/j.tourman.2018.11.006

19. Ivanova, E. \& Cepel, M. (2018). The impact of innovation performance on the competitiveness of the Visegrad 4 countries. Journal of Competitiveness, 10(1), 54-72. doi:10.7441/joc.2018.01.04

20. Jang, S. C. S., Bai, B., Hong, G. S. \& O'Leary, J. T. (2004). Understanding travel expenditure patterns: a study of Japanese pleasure travelers to the United States by income level. Tourism Management, 25(3), 331-341. doi: 10.1016/S0261-5177(03)00141-9

21. Jenco, M. \& Cernak, I. (2019). Application of a confrontation matrix in project teams quality management. Quality-Access to Success, 20(170), 73-77.

22. Jurdana, D. S. \& Frleta, D. S. (2017). Satisfaction as a determinant of tourist expenditure. Current Issues in Tourism, 20(7), 691-704. doi: 10.1080/13683500.2016.1175420

23. Kassambara, A. \& Mundt, F. (2020). Factoextra: extract and visualize the results of multivariate data analyses. R package version 1.0.7. https://CRAN.R-project.org/package=factoextra

24. Kayar, C. H. \& Kozak, N. (2010). Measuring destination competitiveness: an application of the Travel and Tourism Competitiveness Index (2007). Journal of Hospitality Marketing \& Management, 19(3), 203-216. doi: 10.1080/19368621003591319

25. Kim, H. J., Chen, M. H. \& Jang, S. (2006). Tourism expansion and economic development: the case of Taiwan. Tourism Management, 27(5), 925-933. doi: 10.1016/j.tourman.2005.05.011

26. Ključnikov, A., Belás, J., Smrčka, L. (2016). The Role Of Risk-Taking And Competitive Aggressiveness In Management of SMEs. Polish Journal of Management Studies, 14 (1). DOI: 10.17512/pjms.2016.14.1.12

27. Kljucnikov, A., Civelek, M., Cera, G., Mezulanik, J. \& Manak, R. (2020a). Differences in entrepreneurial orientation (EO) of SMEs in the international context: evidence from the Czech Republic and Turkey. Inzinerine Ekonomika-Engineering Economics, 31(3), 345-357. doi: 10.5755/j01.ee.31.3.23933

28. Kljucnikov, A., Civelek, M., Krajcik, C. \& Kmeco, L. (2020b). Innovations in tourism marketing: sharing economy platform. Marketing and Management of Innovations, 1, 11-25. doi: 10.21272/mmi.2020.1-01

29. Kordalska, A. \& Olczyk, M. (2016). Global competitiveness and economic growth: a one-way or two-way relationship? Equilibrium-Quarterly Journal of Economics and Economic Policy, 11(1), 121-142. doi: 10.12775/EQUIL.2016.006

30. Korkmaz, S., Goksuluk, D. \& Zararsiz, G. (2014). MVN: An R package for assessing multivariate normality. The R Journal. 6(2):151-162.

31. Krugman, P. R. (1996). Making sense of the competitiveness debate. Oxford Review of Economic Policy, 12(3), 17-25. 


\section{JOURNAL OF TOURISM AND SERVICES}

Issue 21, volume 11, ISSN 1804-5650 (Online)

www.jots.cz

32. Lall, S. (2001). Competitiveness indices and developing countries: an economic evaluation of the Global competitiveness report. World Development, 29(9), 1501-1525. doi: 10.1016/S0305750X(01)00051-1

33. Maechler, M., Rousseeuw, P., Struyf, A., Hubert, M. \& Hornik, K. (2019). Cluster: cluster analysis basics and extensions. $\mathrm{R}$ package version 2.1.0.

34. Mayer, M. \& Vogt, L. (2016). Economic effects of tourism and its influencing factors. Zeitschrift fur Tourismuswissenschaft, 8(2), 169-198. doi: 10.1515/tw-2016-0017

35. Megyesiova, S. \& Lieskovska, V. (2015). Decomposition of GDP growth and convergence of selected indicators. In: 7th International Scientific Conference on Finance and Performance of Firms in Science, Education and Practice, Apr 23-24, 2015. Edited by: Pastuszkova, E., Crhova, Z., Vychytilova, J., Vytrhlikova, B. \& Knapkova, A., 931-937.

36. Megyesiova, S. \& Lieskovska, V. (2018). Analysis of the sustainable development indicators in the OECD countries. Sustainability, 10(12), 4554. doi: 10.3390/su10124554

37. Nazmfar, H., Eshghei, A., Alavi, S. \& Pourmoradian, S. (2019). Analysis of travel and tourism competitiveness index in middle-east countries. Asia Pacific Journal of Tourism Research, 24(6), 501-513. doi: 10.1080/10941665.2019.1590428

38. Pellegrini, A., Sarman, I. \& Maggi, R. (2020). Understanding tourists' expenditure patterns: a stochastic frontier approach within the framework of multiple discrete-continuous choices. Transportation. doi: 10.1007/s11116-020-10083-2

39. Perez-Moreno, S., Rodriguez, B. \& Luque, M. (2016). Assessing global competitiveness under multi-criteria perspective. Economic Modelling, 53, 398-408, doi: 10.1016/j.econmod.2015.10.030

40. Pulido-Fernandez, J. I. \& Cardenas-Garcia, P. J. (2020). Analyzing the bidirectional relationship between tourism growth and economic development. Journal of Travel Research. doi: $10.1177 / 0047287520922316$

41. Pulido-Fernandez, J. I. \& Pulido-Fernandez, M. D. (2018). Proposal for an indicators system of tourism governance at tourism destination level. Social Indicators Research, 137(2), 695-743. doi: $10.1007 / \mathrm{s} 11205-017-1627-\mathrm{z}$

42. Pulido-Fernandez, J. I., Rodriguez-Diaz, B. \& Cardenas-Garcia, P. J. (2020). Key factors of tourism expenditure in emerging urban-cultural destinations. Anatolia-International Journal of Tourism and Hospitality Research, 31(1), 31-49. doi: 10.1080/13032917.2019.1691615

43. R Core Team (2020). R: A language and environment for statistical computing. R Foundation for Statistical Computing, Vienna, Austria. from https://www.R-project.org/.

44. Rossello-Nadal, J. \& Jianan, H. E. (2019). Tourist arrivals versus tourist expenditures in modelling tourism demand. Tourism Economics, UNSP 1354816619867810. doi: $10.1177 / 1354816619867810$

45. Royston, J. P. (1982). An extension of Shapiro and Wilks w test for normality to large samples. Applied Statistics, 31(2), 115-124.

46. Seetanah, B. (2011). Assessing the dynamic economic impact of tourism for Island economies. Annals of Tourism Research, 38(1), 291-308. doi: 10.1016/j.annals.2010.08.009

47. Song, H. Y., Li, G. \& Cao, Z. (2018). Tourism and economic globalization: an emerging research agenda. Journal of Travel Research, 57(8), 999-1011. doi: 10.1177/0047287517734943

48. Stefko, R., Vasanicova, P., Litavcova, E. \& Jencova, S. (2018). Tourism intensity in the NUTS III regions of Slovakia. Journal of Tourism and Services, 9(16), 45-59. doi: 10.29036/jots.v9i16.43

49. Struyf, A., Hubert, M. \& Rousseeuw, P. J. (1996). Clustering in an object-oriented environment. Journal of Statistical Software, 1, 1-30. doi: 10.18637/jss.v001.i04 


\section{JOURNAL OF TOURISM AND SERVICES}

Issue 21, volume 11, ISSN 1804-5650 (Online)

www.jots.cz

50. Suh, Y. K. \& Gartner, W. C. (2004). Preferences and trip expenditures - a conjoint analysis of visitors to Seoul, Korea. Tourism Management, 25(1), 127-137. doi: 10.1016/S02615177(03)00056-6

51. Tavares, J. M., Ivanov, S. \& Neves, O. F. (2016). Determinant of tourists' spending during tours: the case of repeat vs. first-time visitors to State Minas Gerais, Brazil. Tourism Planning \& Development, 13(1), 23-36. doi: 10.1080/21568316.2015.1074094

52. Usmani, G., Akram, V. \& Praveen, B. (2020). Tourist arrivals, international tourist expenditure, and economic growth inBRICcountries. Journal of Public Affairs. doi: 10.1002/pa.2202

53. WB. (2020). Total population. Retrieved February 8, 2020, from https://data.worldbank.org/indicator/SP.POP.TOTL

54. WEF. (2019). The Travel and Tourism Competitiveness Report 2019. Retrieved July 4, 2020, from http://www3.weforum.org/docs/WEF_TTCR_2019.pdf

55. WEF. (2020). Global Competitiveness Index. Retrieved February 8, 2020, from https://www.weforum.org/reports

56. White, H. A. (1980). Heteroskedasticity-consistent covariance-matrix estimator and a direct test for heteroskedasticity. Econometrica, 48(4), 817-838. doi: 10.2307/1912934

57. Wickham. H. (2016). Ggplot2: elegant graphics for data analysis. Springer-Verlag New York

58. WTTC. (2020). Tourism expenditure. Retrieved February 8, 2020, from https://tool.wttc.org/

59. Zeileis A. (2004). Econometric computing with HC and HAC covariance matrix estimators. Journal of Statistical Software. 11(10), 1-17. doi: 10.18637/jss.v011.i10

60. Zeileis, A. \& Hothorn, T. (2002). Diagnostic checking in regression relationships. R News 2(3), $7-10$.

\section{Brief description of Authors:}

\section{Prof. Beata Gavurova, Ph.D.}

Institute of Earth Resources, Faculty of Mining, Ecology, Process Control and Geotechnologies, Technical university of Košice, Park Komenského 19, 04200 Košice, Slovakia.

She is an expert in finance, financial analysis and financial risk management. She focuses in her research work on issues of measurement and performance management in various sectors, process management and process optimization, strategic and performance benchmarking. Her dominant research area is the development and testing in the management and performance measurement, the evaluation of methodologies and the preparation of an application platform for innovative management and performance measurement with the support of ICT. ORCID ID: https://orcid.org/0000-0002-0606$\underline{879 X}$

\section{Mgr. Viera Ivankova}

Department of Economics and Economy, Faculty of Management, University of Prešov, Konštantínova 16, 08001 Prešov, Slovakia, martin.rigelsky@gmail.com.

Viera Ivankova is a doctoral student at the Department of Economics and Economy of the University of Prešov. Her dominant areas of expertise are macroeconomics and microeconomics. In her scientific and research activities, she mainly focuses on health economics, addictology and tourism. ORCID ID: https://orcid.org/0000-0002-6164-1165

\section{Mgr. Martin Rigelsky}

Department of Marketing and International Trade, Faculty of Management, University of Prešov, Konštantínova 16, 08001 Prešov, Slovakia, martin.rigelsky@gmail.com.

He currently works at the Department of Marketing and International Trade at the Faculty of Management of the University of Prešov. His scientific activities include, in particular, research in the 
field of economics with a focus on public health and tourism. He deals secondarily with marketing and customer behaviour. ORCID ID: https://orcid.org/0000-0003-1427-4689

\section{Prof. Dr. Magdaléna Př́varová}

Department of Economics, the University of Economics in Bratislava, Dolnozemská cesta 1, 85235 Bratislava, Slovak Republic, magdalena.privarova@euba.sk.

Her research interests include international migration, EU labour market, and international regulation of labour migration and Enterprise Economics. She is the author of 13 Web of Science and 7 Scopus scientific papers. 